\title{
The concept of sustainability applied to an industrial sludge deposit
}

\author{
Mariana-Florentina Ștefănescu ${ }^{1}$, Alexandru Dobrovicescu ${ }^{1}$, Iuliana-Marlena Prodea ${ }^{1}$, and \\ Nicoleta Sporea $^{1 *}$ \\ ${ }^{1}$ University POLITEHNICA of Bucharest, Faculty of Mechanical Engineering and Mechatronics, 313 \\ Spl. Independenței, 060042 Romania
}

\begin{abstract}
The paper presents an environmental impact study in a real case: a landfill containing hazardous substances, held by an economic operator in an area near a city. The sludge storage was monitored taking into account three main impact factors: soil, groundwater and leachate. The actual environmental status of the storage area is assessed by calculating these impact factors before and during ten years of storage and the global pollution index.
\end{abstract}

\section{Introduction}

Industrial waste deposits are encountered in all industrial processes. Almost every industry either generates hazardous waste or uses products from industries that produce hazardous waste. All sludge from industrial wastewater treatment contains hazardous substances which, depending on their content and percentage, endanger the health of population and the environment. The presence of heavy metals is a real problem for the environment.

The way these wastes are landfilled must be pursued through a monitoring activity of the environmental factors affected by the presence of waste. The values of the impact factors showing that the environment is not affected give to the industrial activities, responsible for generating and managing these wastes, the status of sustainable development. In the literature [1-6] there have been studies on the impact of deposits from various industrial sources.

The monitoring of environmental factors for the exploitation phase is based on the provisions of the current legislation elaborated on the basis of Directive 1999/31/EC on the landfill of waste, as subsequently amended and supplemented and Directive 2008/98/EC on waste disposal of certain directives [7-9].

The paper presents the environmental impact of a sludge deposit resulting from the purification of the wastewater obtained in the galvanizing process of the drawn steel wire. The sludge is generated from two sources of wastewater: the galvanizing thermal process and the neutralization process of acidic waters by the precipitation of heavy metals as hardly soluble hydroxides. The sludge thus separated has high water content (about 85$95 \%$ ). Therefore, before being evacuated, the sludge cake is subjected to a dehydration process, so that its final humidity is max. $60 \%$.

\footnotetext{
* Corresponding author: nsporea@yahoo.com
} 
The sludge storage cell is made in accordance with legal requirements with a waterproofing barrier with clay, bentonite and high density geomembrane.

The impact of the deposit on the environment during the exploitation period is determined by comparing the values of the environmental factors in the reference samples before the site is made and during the storage period. Thus, water and soil samples were taken from the storage area and the adjacent area before the industrial sludge was stored and during ten years of storage. The monitored environmental factors were: soil, groundwater and leachate. The presence of heavy metals $(\mathrm{Cu}, \mathrm{Fe}, \mathrm{Zn})$ that exceeded the alert limits at the beginning of storage was found. The explanation was given by the presence of a second non-compliant deposit of substances from a steel plant that ceased activity without being monitored and treated. The quality of environmental factors has been assessed by the individual Pollution Indices, which determined the global effect of the deposit on the environment through the Global Pollution Index (IpG) chart. The conclusion of the study is that the environment is subjected to human activity within acceptable limits.

\section{Investigation methods}

The environmental impact produced by sludge during the exploitation period was established using the Illustrative Method of Assessing the Environmental Quality Status [10]. This method assesses the impact of industrial activity on each environmental factor as well as the associated impact of environmental factors. The quality of each environmental factor is framed by a creditworthiness scale, by providing notes that show proximity or distance from the ideal state. The creditworthiness scale is expressed by numbers from 1 to 10 , in which 1 represents the irreversible and particularly serious deterioration of the analysed environmental factor, and 10 the natural state, unaffected by the industrial activity. The credit scores for each environmental factor are based on the norms in force.

The quality of environmental factors is estimated by the Pollution Index, Ip, which is calculated by dividing the maximum concentration of the measured pollutant, $\mathrm{C}_{\max }$, to the maximum allowable concentration according to the legislation in force, $\mathrm{C}_{\mathrm{a}}$ :

$$
I p=\frac{C_{\max }}{C_{a}}
$$

The values of the Pollution Index, the corresponding creditworthiness notes and the correlation with the effect on the environment are presented in Table 1.

Table 1. Pollution Index, the corresponding creditworthiness notes and the correlation with the effect on the environment [10].

\begin{tabular}{|c|c|l|}
\hline $\begin{array}{c}\text { Pollution } \\
\text { Index (Ip) }\end{array}$ & $\begin{array}{c}\text { Creditworthiness } \\
\text { note }\end{array}$ & \multicolumn{1}{c|}{ The effect on the environment } \\
\hline 0 & 10 & $\begin{array}{l}\text { Environment unaffected by human activity, natural } \\
\text { environment. }\end{array}$ \\
\hline$(0.0-0.2]$ & 9 & $\begin{array}{l}\text { The environment affected by human activity, without } \\
\text { quantifiable effects. }\end{array}$ \\
\hline$(0.2-0.7]$ & 8 & $\begin{array}{l}\text { The environment is affected within the permissible: } \\
\text { level 1. Alert limit: with potential effects. }\end{array}$ \\
\hline$(0.7-1.1]$ & 7 & $\begin{array}{l}\text { The environment is affected within acceptable: level } 2 \\
\text { limit. Intervention threshold: significant effects. }\end{array}$ \\
\hline$(1.1-2.0]$ & 6 & $\begin{array}{l}\text { The environment is affected within acceptable limits: } \\
\text { level 1. Alert limit: with potential effects. }\end{array}$ \\
\hline$(2.0-4.0]$ & 5 & $\begin{array}{l}\text { The environment is affected within acceptable limits: } \\
\text { level 2. Intervention level: significant effects }\end{array}$ \\
\hline
\end{tabular}




\begin{tabular}{|c|c|l|}
\hline $\begin{array}{c}\text { Pollution } \\
\text { Index (Ip) }\end{array}$ & $\begin{array}{c}\text { Creditworthiness } \\
\text { note }\end{array}$ & \multicolumn{1}{c|}{ The effect on the environment } \\
\hline$(4.0-8.0]$ & 4 & $\begin{array}{l}\text { The environment is affected within the admissible } \\
\text { level: } 3 \text { limits. Harmful effects are highlighted. }\end{array}$ \\
\hline$(8.0-12.0]$ & 3 & $\begin{array}{l}\text { The environment is degraded to level 1. The effects are } \\
\text { lethal at average exposure times. }\end{array}$ \\
\hline$(12.0-20.0]$ & 2 & $\begin{array}{l}\text { The environment is degraded level 2. The effects are } \\
\text { lethal at short exposure times. }\end{array}$ \\
\hline$>20.0$ & 1 & The environment is inappropriate for life forms. \\
\hline
\end{tabular}

One of the most important steps is to identify the full impact effect of pollution factors analysed. The Creditworthiness notes for each environmental factor in the analyzed area serve to graphically plot a chart as a method of simulating synergic effects.

The ideal state is represented graphically by a regular geometric shape - area $\mathrm{S}_{0}$ - with the sides having the value of 10 Creditworthiness notes for the analyzed environmental factors. The values of the corresponding Creditworthiness notes of each measured environmental factor are represented in the ideal state graph. An irregular geometrical figure having a surface $\left(\mathrm{S}_{\mathrm{r}}\right)$ smaller than ideal one $\left(\mathrm{S}_{0}\right)$ results. The global pollution status of the environment is evaluated by the Global Pollution Index $\left(\mathrm{Ip}_{\mathrm{G}}\right)$ calculated with the relationship:

$$
I p_{G}=\frac{S_{0}}{S_{r}}
$$

When there are changes in environmental factors, $\mathrm{Ip}_{\mathrm{G}}$ will have higher supraunit values as the surface geometry figure reduces. For the Global Pollution Index, a scale of 1 to 6 was admitted (Table 2).

Table 2. The Global Pollution Index $\left(\mathrm{Ip}_{\mathrm{G}}\right)$ of an ecosystem and its effect on the environment [10].

\begin{tabular}{|c|l|}
\hline $\begin{array}{c}\text { Global Pollution } \\
\left.\text { Index } \mathbf{( I p}_{\mathbf{G}}\right)\end{array}$ & \multicolumn{1}{c|}{ The effect on the environment } \\
\hline 1 & Environment unaffected by human activity, natural environment. \\
\hline$(1-2)$ & Environment subjected by human activity within acceptable limits. \\
\hline$[2-3)$ & $\begin{array}{l}\text { Environment subjected by human activity that causes discomfort to life } \\
\text { forms. }\end{array}$ \\
\hline$[3-4)$ & Environment affected by human activity, causing disturbances to life forms. \\
\hline$[4-6)$ & Environment seriously affected by human activity, dangerous to life forms. \\
\hline$\geq 6$ & Degraded environment, improperly for life forms. \\
\hline
\end{tabular}

The method has the advantage that it offers the possibility of establishing a direct link between the quality of the environment and the health of the population.

\section{Experiments}

Objectives pursued are: monitoring the technological waste characteristics; soil monitoring in the area of influence of the deposit - by sampling 4 points (on each side of the deposit) at two different depths $(5 \mathrm{~cm}$ and $30 \mathrm{~cm})$; ground water monitoring - through control drilling at least three points in the flow direction (one point upstream and two downstream from the warehouse); leachate monitoring.

Heavy metals are defined as factors of concern/interest that represent the hazardous part of the waste. And these are: $\mathrm{Fe}, \mathrm{Cu}$ and $\mathrm{Zn}$ that are found in the waste of the technological process studied. 


\subsection{The characterization of the sludge produced by the treatment of wastewater from the technological process}

The monitoring period of the deposit began at the opening and took place over a period of ten years. The galvanizing thermal process has used the same raw materials and technologies throughout all the monitoring period. This resulted in the same average daily composition of the sludge containing dangerous substances - heavy metals (Table 3).

Table 3. The chemical composition of the sludge at the beginning of the storage operation and after ten years.

\begin{tabular}{|c|c|c|c|}
\hline \multirow{2}{*}{$\begin{array}{c}\text { Measured } \\
\text { indicator }\end{array}$} & $\begin{array}{c}\text { Permissible limit } \\
\text { values (mg/kg s.u.) }\end{array}$ & \multicolumn{2}{|c|}{ Measured values (mg/kg s.u.) } \\
\cline { 3 - 4 } & [7] & at the opening & after ten years \\
\hline $\mathrm{As}$ & 25 & $<0.05$ & $<0.05$ \\
\hline $\mathrm{Ba}$ & 30 & 0.03 & 0.07 \\
\hline $\mathrm{Cd}$ & 5 & 0.01 & $<0.01$ \\
\hline $\mathrm{Cr}$ total & 70 & 0.03 & 0.015 \\
\hline $\mathrm{Cu}$ & 100 & $<0.04$ & 0.1 \\
\hline $\mathrm{Hg}$ & 2 & $<0.05$ & $<0.05$ \\
\hline $\mathrm{Mo}$ & 30 & $<0.01$ & 0.16 \\
\hline $\mathrm{Ni}$ & 40 & 0.88 & 0.66 \\
\hline $\mathrm{Pb}$ & 50 & $<0.05$ & $<0.05$ \\
\hline $\mathrm{Sb}$ & 5 & $<0.05$ & $<0.05$ \\
\hline $\mathrm{Se}$ & 7 & $<0.1$ & 0.12 \\
\hline $\mathrm{Zn}$ & 200 & 2.47 & 0.56 \\
\hline
\end{tabular}

By analysing the composition of the sludge (Table 3), much lower concentrations are observed compared to the values set in the legislation, which makes the sludge produced by treating the wastewater, from the technological process, to be stored as it is, being conform with Best Available Techniques for the Waste Treatments Industries [8, 9].

\subsection{Land quality monitoring before storage}

The deposit is located in the immediate vicinity of the factory which produces the sludge. There are no natural waters or rivers or lakes on the territory related to the studied objective. The samples were taken from each side of the deposit at 2 different depths ( 5 and $30 \mathrm{~cm}$ ) and contain heavy metals. The depths were chosen so that any contamination in the depth could be estimated. Samples P1, P3, P5 and P7 were taken from a depth of $5 \mathrm{~cm}$ and samples P2, P4, P6 and P8 from a depth of $30 \mathrm{~cm}$. Following the soil samples analysed taken prior to the commissioning of the deposit, copper, lead, zinc, manganese are present under the normal limits established by the regulations, as well as ferric oxide, which is not regulated by normative acts. The composition of the soil is shown in Table 4 .

Table 4. Land quality before storage: measured values vs. limits.

\begin{tabular}{|c|c|c|c|c|c|c|c|}
\hline \multirow{3}{*}{ Sample } & \multirow{3}{*}{$\begin{array}{l}\text { Side of } \\
\text { the } \\
\text { deposit }\end{array}$} & \multirow{3}{*}{$\begin{array}{c}\text { Pollutant } \\
\text { determined }\end{array}$} & \multicolumn{3}{|c|}{$\begin{array}{l}\text { Limits [7-9] } \\
\text { (mg/kg s.u.) }\end{array}$} & \multirow{2}{*}{\multicolumn{2}{|c|}{$\begin{array}{l}\text { Measured values } \\
\text { (mg/kg s.u.) }\end{array}$}} \\
\hline & & & \multirow[b]{2}{*}{$\begin{array}{l}\text { normal } \\
\text { values }\end{array}$} & \multirow{2}{*}{$\begin{array}{c}\text { alert } \\
\text { thres- } \\
\text { hold }\end{array}$} & \multirow{2}{*}{$\begin{array}{c}\text { inter- } \\
\text { venetion } \\
\text { thres- } \\
\text { hold } \\
\end{array}$} & & \\
\hline & & & & & & 5 & 30 \\
\hline \multirow{2}{*}{$\mathrm{P} 1, \mathrm{P} 2$} & \multirow{2}{*}{ East } & $\mathrm{Cu}$ & 20 & 100 & 200 & 19.4 & 11.2 \\
\hline & & $\mathrm{Pb}$ & 20 & 50 & 100 & 8.3 & 1.1 \\
\hline
\end{tabular}




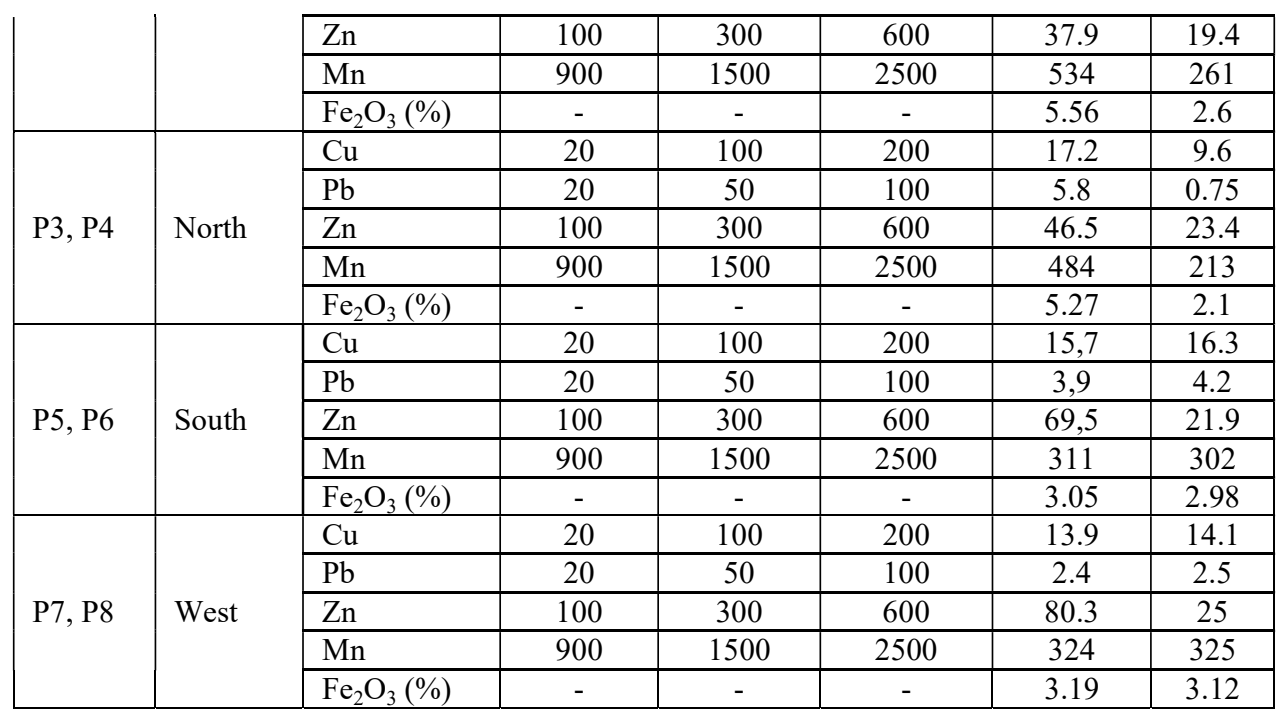

\subsection{Land quality monitoring after ten years of storage and environmental impact}

Values measured after 10 years of storage (Table 5) are below the normal values shown in Table 3, except for the $\mathrm{Cu}$ indicator. The concentration of this indicator at both the $5 \mathrm{~cm}$ and the $30 \mathrm{~cm}$ depths, for all samples, does not exceed the alert and intervention thresholds as is shown in Table 4. In Table 5 are also calculated the values of the Pollution Index.

Table 5. Land quality monitoring after ten years of storage

\begin{tabular}{|c|c|c|c|c|c|c|}
\hline \multirow{3}{*}{ Sample } & \multirow{3}{*}{$\begin{array}{l}\text { Side of } \\
\text { the } \\
\text { deposit }\end{array}$} & \multirow{3}{*}{$\begin{array}{c}\text { Pollutant } \\
\text { determined }\end{array}$} & \multicolumn{2}{|c|}{$\begin{array}{c}\text { Measured values } \\
\text { (mg/kg s.u.) }\end{array}$} & \multicolumn{2}{|c|}{$\begin{array}{l}\text { Pollution Index } \\
\text { (Ip) }\end{array}$} \\
\hline & & & \multicolumn{2}{|c|}{ depth $(\mathrm{cm})$} & \multicolumn{2}{|c|}{ depth $(\mathrm{cm})$} \\
\hline & & & 5 & 30 & 5 & 30 \\
\hline \multirow{5}{*}{ P1, P2 } & \multirow{5}{*}{ East } & $\mathrm{Cu}$ & 37.8 & 38.8 & 1.89 & 1.94 \\
\hline & & $\mathrm{Pb}$ & 13.4 & 12.5 & 0.67 & 0.625 \\
\hline & & $\mathrm{Zn}$ & 58.9 & 61.7 & 0.589 & 0.617 \\
\hline & & $\mathrm{Mn}$ & 575 & 584 & 0.639 & 0.649 \\
\hline & & $\mathrm{Fe}_{2} \mathrm{O}_{3}(\%)$ & 128 & 123 & - & - \\
\hline \multirow{5}{*}{ P3, P4 } & \multirow{5}{*}{ North } & $\mathrm{Cu}$ & 35.2 & 37.4 & 1.76 & 1.87 \\
\hline & & $\mathrm{Pb}$ & 9.4 & 9.8 & 0.47 & 0.49 \\
\hline & & $\mathrm{Zn}$ & 46.7 & 48.3 & 0.467 & 0.483 \\
\hline & & $\mathrm{Mn}$ & 556 & 567 & 0.618 & 0.63 \\
\hline & & $\mathrm{Fe}_{2} \mathrm{O}_{3}(\%)$ & 132 & 137 & - & - \\
\hline \multirow{5}{*}{ P5, P6 } & \multirow{5}{*}{ South } & $\mathrm{Cu}$ & 31.5 & 33.7 & 1.575 & 1.685 \\
\hline & & $\mathrm{Pb}$ & 11.6 & 11.8 & 0.58 & 0.59 \\
\hline & & $\mathrm{Zn}$ & 53.2 & 56.3 & 0.532 & 0.563 \\
\hline & & $\mathrm{Mn}$ & 537 & 541 & 0.597 & 0.601 \\
\hline & & $\mathrm{Fe}_{2} \mathrm{O}_{3}(\%)$ & 125 & 130 & - & - \\
\hline \multirow{5}{*}{ P7, P8 } & \multirow{5}{*}{ West } & $\mathrm{Cu}$ & 27.8 & 28.2 & 1.35 & 1.41 \\
\hline & & $\mathrm{Pb}$ & 8.4 & 9.6 & 0.42 & 0.48 \\
\hline & & $\overline{\mathrm{Zn}}$ & 71.3 & 78.4 & 0.713 & 0.784 \\
\hline & & $\mathrm{Mn}$ & 588 & 571 & 0.653 & 0.634 \\
\hline & & $\mathrm{Fe}_{2} \mathrm{O}_{3}(\%)$ & 119 & 121 & - & - \\
\hline
\end{tabular}


The highest level of pollution of the land, calculated with normal values (Table 4) and relation (1), is recorded in the eastern part of the deposit (P1, P2) for $\mathrm{Cu}$. These values correspond to Creditworthiness note 6: The environment is affected within acceptable limits: Level 1. Alert limit: potential effects. For the elements $\mathrm{Pb}$ and $\mathrm{Mn}$ the level of pollution correspond to Creditworthiness note 8: The environment is affected within the permissible: level 1. Alert limit: with potential effects. Zinc pollution level has the creditworthiness note 6 , with the exception of the western area where, for both depths, the creditworthiness note is 7: The environment is affected within acceptable: level 2 limit. Intervention threshold: significant effects.

\subsection{Groundwater monitoring}

Water samples were taken by carrying out three drillings in the direction of flow of groundwater (a point located upstream and two downstream from the deposit) in accordance with environmental regulations before commencement of storage (reference values) and every six months of operation. In Table 6 the results are presented only for drilling 2, as the synthesis of the results is presented in full in Table 7. The following indicators were measured: $\mathrm{pH}$, total ionic $\mathrm{Fe}$, chlorides, $\mathrm{CCO}-\mathrm{Cr}, \mathrm{CBO}_{5}$, ammoniacal nitrogen, nitrates, sulphates, copper, zinc.

Table 6. Groundwater monitoring: measurement values vs. reference values.

\begin{tabular}{|c|c|c|c|c|c|c|c|c|c|c|}
\hline $\begin{array}{c}\text { Date } \\
\text { of } \\
\text { sam- } \\
\text { pling } \\
\text { (mon } \\
\text { ths) }\end{array}$ & pH & $\begin{array}{c}\text { CCO- } \\
\text { Cr } \\
\text { mg/l }\end{array}$ & $\underset{\mathrm{mg} / \mathrm{l}}{\mathrm{CBO}_{5}}$ & $\begin{array}{c}\text { A- } \\
\text { mm- } \\
\text { onia- } \\
\text { cal } \\
\text { nitro- } \\
\text { gen } \\
\text { mg/l }\end{array}$ & $\begin{array}{c}\text { Nitra- } \\
\text { tes } \\
\mathrm{mg} / \mathrm{l}\end{array}$ & $\begin{array}{c}\text { Chlo- } \\
\text { rides } \\
\mathrm{mg} / \mathrm{l}\end{array}$ & $\begin{array}{c}\text { Sul- } \\
\text { phates } \\
\text { mg/l }\end{array}$ & $\begin{array}{c}\mathbf{F e} \\
\mathbf{m g} / \\
\mathbf{l}\end{array}$ & $\begin{array}{c}\mathrm{Cu} \\
\mathrm{mg} / \\
\mathbf{l}\end{array}$ & $\begin{array}{c}\mathrm{Zn} \\
\mathrm{mg} / \\
\mathrm{l}\end{array}$ \\
\hline \multicolumn{11}{|c|}{ Point drilling 2} \\
\hline \multicolumn{11}{|c|}{ Reference values } \\
\hline $\begin{array}{l}\text { before } \\
\text { storage }\end{array}$ & 7.27 & 24 & 7.56 & 0.42 & 0.92 & 220.6 & 515.1 & 0.47 & 0.04 & 0.01 \\
\hline \multicolumn{11}{|c|}{ Experimental measurements } \\
\hline after 6 & 6.71 & 33 & 8.85 & 0.54 & 0.98 & 236.4 & 529.7 & 0.58 & 0.05 & 0.02 \\
\hline after 12 & 7.38 & 16 & 7.41 & 0.47 & 0.98 & 232.5 & 543.4 & 0.48 & 0.05 & 0.02 \\
\hline after 18 & 7.39 & 18 & 7.82 & 0.48 & 0.82 & 211.6 & 521.8 & 0.44 & 0.05 & 0.03 \\
\hline after 24 & 7.42 & 21 & 9.2 & 0.4 & 0.72 & 204.3 & 505.8 & 0.41 & $\mathbf{0 . 0 7}$ & 0.04 \\
\hline after 30 & 7.4 & 20.4 & 9.04 & 0.44 & 0.77 & 211.5 & 510.7 & 0.4 & 0.06 & 0.05 \\
\hline after 36 & 7.33 & 19.7 & 8.14 & 0.81 & 0.56 & 192.3 & 527.6 & 0.38 & 0.03 & 0.01 \\
\hline after 42 & 7.31 & 21.3 & 8.93 & 0.36 & 0.34 & 66.5 & 58.3 & 0.13 & 0.03 & 0.01 \\
\hline
\end{tabular}

Measurements have shown an abnormal excess from reference values in the early years since the start of the warehouse operation, although the technological process has remained unchanged. The most significant differences, in comparison with baseline values, were recorded in the first 42 months at all three drilling points for almost all indicators (bold values in Table 6). Table 7 shows the values of the Pollution Index for the highest overcomes of the reference values and the effects of their presence on the environment.

The environmental impact for all monitored parameters is in Creditworthiness note 7: The environment is affected within acceptable: level 2 limit. Intervention threshold: significant effects and Creditworthiness note 6: The environment is affected within acceptable limits: Level 1. Alert limit: potential effects, except Zn. This indicator has, in 
drilling point 2, Creditworthiness note 4: The environment is affected within the admissible level: 3 limits. Harmful effects are highlighted.

Table 7. The Pollution Index for the highest overcome of reference values and the corresponding Creditworthiness note.

\begin{tabular}{|c|c|c|c|c|c|c|c|c|c|}
\hline pH & $\begin{array}{c}\text { CCO- } \\
\mathbf{C r} \\
\mathrm{mg} / \mathrm{l}\end{array}$ & $\underset{\mathrm{mg} / \mathrm{l}}{\mathrm{CBO}_{5}}$ & $\begin{array}{c}\text { A- } \\
\text { mm- } \\
\text { onia- } \\
\text { cal } \\
\text { nitro- } \\
\text { gen } \\
\text { mg/l } \\
\end{array}$ & $\begin{array}{c}\text { Nitra- } \\
\text { tes } \\
\text { mg/l }\end{array}$ & $\begin{array}{c}\text { Chlori } \\
\text {-des } \\
\text { mg/l }\end{array}$ & $\begin{array}{c}\text { Sul- } \\
\text { phates } \\
\text { mg/l }\end{array}$ & $\begin{array}{c}\mathrm{Fe} \\
\mathrm{mg} / \mathrm{l}\end{array}$ & $\underset{\mathrm{mg} / \mathrm{l}}{\mathrm{Cu}}$ & $\begin{array}{c}\mathrm{Zn} \\
\mathrm{mg} / \mathrm{l}\end{array}$ \\
\hline \multicolumn{10}{|c|}{ Point drilling 1} \\
\hline \multicolumn{10}{|c|}{ Pollution Index (Ip) } \\
\hline 1.048 & 1.104 & 1.087 & 1.156 & 1.090 & 1.243 & 1.071 & 1.231 & 1.75 & 2 \\
\hline \multicolumn{10}{|c|}{ Creditworthiness note } \\
\hline 7 & 6 & 7 & 6 & 7 & 6 & 7 & 6 & 6 & 6 \\
\hline \multicolumn{10}{|c|}{ Point drilling 2} \\
\hline \multicolumn{10}{|c|}{ Pollution Index (Ip) } \\
\hline 1.021 & 1.375 & 1.217 & 1.928 & 1.065 & 1.072 & 1.055 & 1.234 & 1.75 & 5 \\
\hline \multicolumn{10}{|c|}{ Creditworthiness note } \\
\hline 7 & 6 & 6 & 6 & 7 & 7 & 7 & 6 & 6 & 4 \\
\hline \multicolumn{10}{|c|}{ Point drilling 3} \\
\hline \multicolumn{10}{|c|}{ Pollution Index (Ip) } \\
\hline 1.031 & 0.915 & 1.137 & 1.159 & 1.145 & 1.113 & 1.055 & 1.267 & 1.25 & 1 \\
\hline \multicolumn{10}{|c|}{ Creditworthiness note } \\
\hline 7 & 7 & 6 & 6 & 6 & 6 & 7 & 6 & 6 & 7 \\
\hline
\end{tabular}

In order to analyse the impact on the territory related to the studied objective, it must be said that there is also a non-permeable deposit nearby, from another industrial operator, operable at the time of construction of our deposit, which had stockade steel slag.

This proximity with steel slag from the non-permeable deposit and operating in the first 4 years at the time of measurements is the cause of abnormal values for $\mathrm{Fe}, \mathrm{Cu}$ and $\mathrm{Zn}$ factors in the first 7 measurements performed during the first 42 months of monitoring. The leachates caused by rain have increased the percentage of $\mathrm{Fe}$ in groundwater. The reference value for $\mathrm{Fe}(0.47)$ was also influenced by the leachate in the non-impermealized deposit.

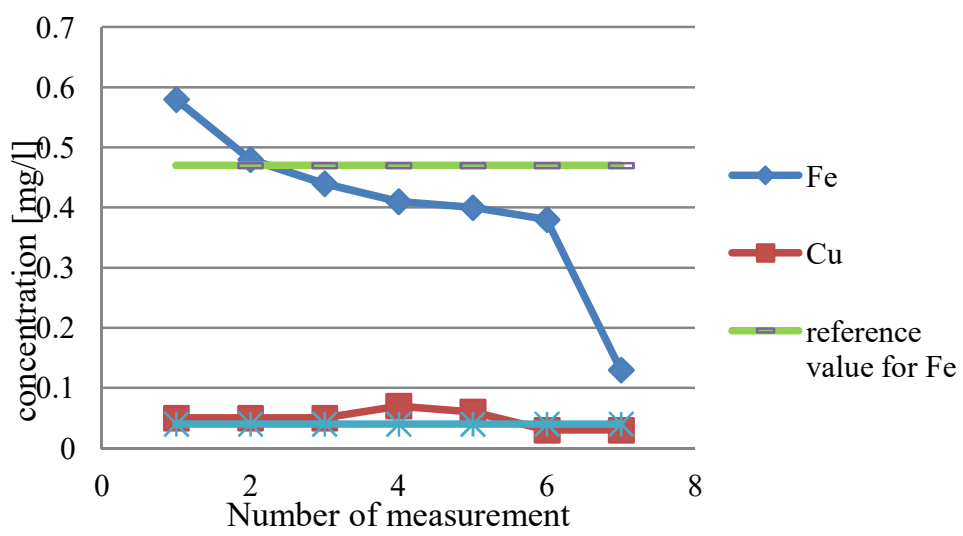

Fig. 1. Concentration in $\mathrm{Fe}$ and $\mathrm{Cu}$ in groundwater during the first 42 months of monitoring (point drilling 2) 
Figure 1 and 2 show the highest Fe input from the non-permeable deposit (obtained at the second drilling) in groundwater, compared to $\mathrm{Zn}$ and $\mathrm{Cu}$ participations. These parameters begin to decrease after closing the steel slag deposit, exhibiting variations below the reference values (Table 6).

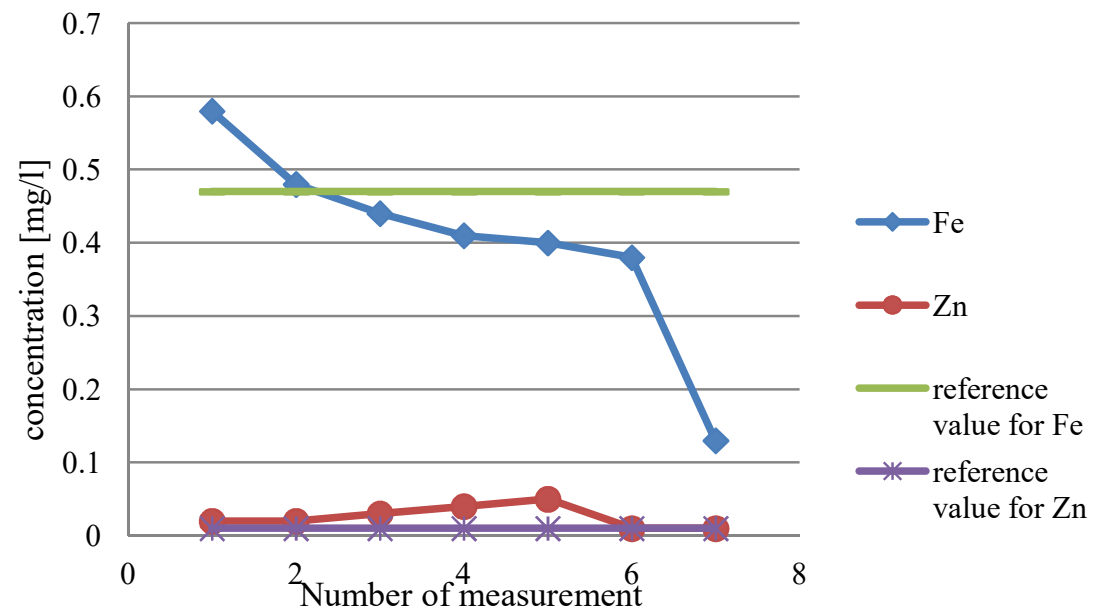

Fig. 2. Concentration in $\mathrm{Fe}$ and $\mathrm{Zn}$ in groundwater during the first 42 months of monitoring (point drilling 2)

\subsection{Leachate monitoring}

It is also necessary to monitor the leachate captured in the collector basin. The parameters to be monitored and the frequency of their determination is the following: total ion iron, copper, zinc - once a quarter every year beginning with the fourth year of depositing. The results are shown in Figures 3 and 4.

Table 8 presents the reference values for concentrations of heavy metals in the leachate, the Pollution Index calculated for the maximum measured values (Fig. 3 and 4) and the creditworthiness notes.

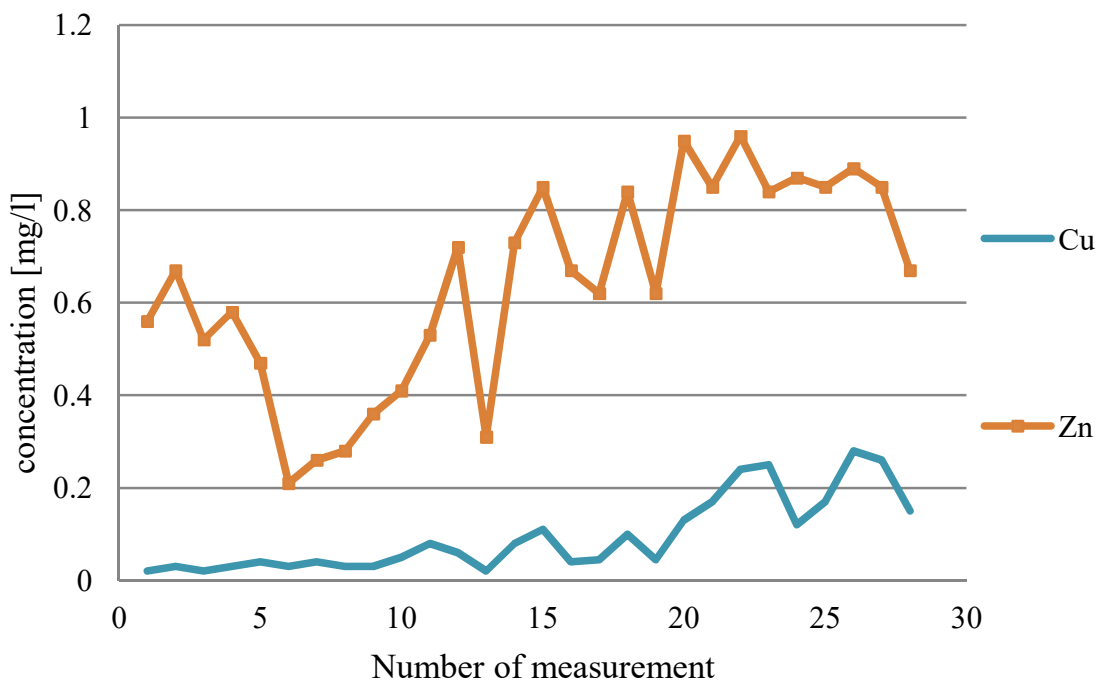

Fig. 3. Results of leachate monitoring for $\mathrm{Cu}$ and $\mathrm{Zn}$ 


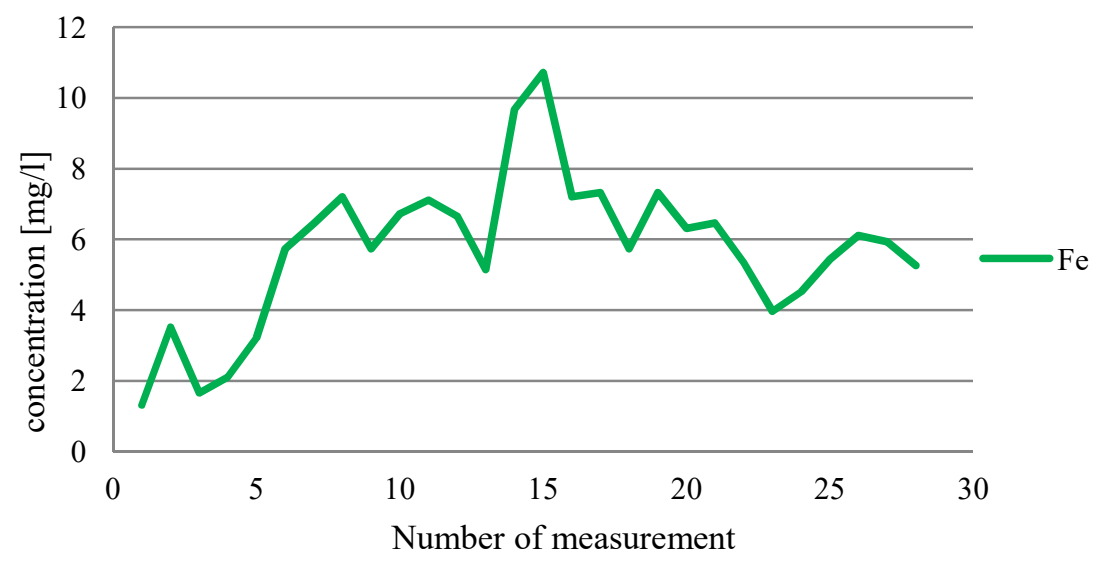

Fig. 4. Results of leachate monitoring for $\mathrm{Fe}$

Table 8. The values for concentrations of heavy metals in the leachate, Pollution Index and the creditworthiness notes.

\begin{tabular}{|l|c|c|c|}
\hline & $\mathbf{C u}$ & $\mathbf{Z n}$ & Total ion Fe \\
\hline Reference value from legislation in force [mg/l] & 10 & 10 & Not specified \\
\hline Maxim value of measured concentration [mg//] & 0.28 & 0.96 & 10.72 \\
\hline Pollution Index (Ip) & 0.028 & 0.096 & - \\
\hline Creditworthiness note & 9 & 9 & - \\
\hline
\end{tabular}

The effect of the $\mathrm{Cu}$ and $\mathrm{Zn}$ content from the leachate produced by sludge deposition results from the analysed process of technology is included in the Creditworthiness notes 9 (Table 1): The environment affected by human activity, without quantifiable effects.

\subsection{The cumulative effect of factors}

In order to determine the global impact of the measured pollutants on the environment, the Global Pollution Index $\left(\operatorname{Ip}_{\mathrm{G}}\right)$ chart is built. The geometric figure is a triangle with data for three quality factors: soil, groundwater and leachate (Fig. 5).

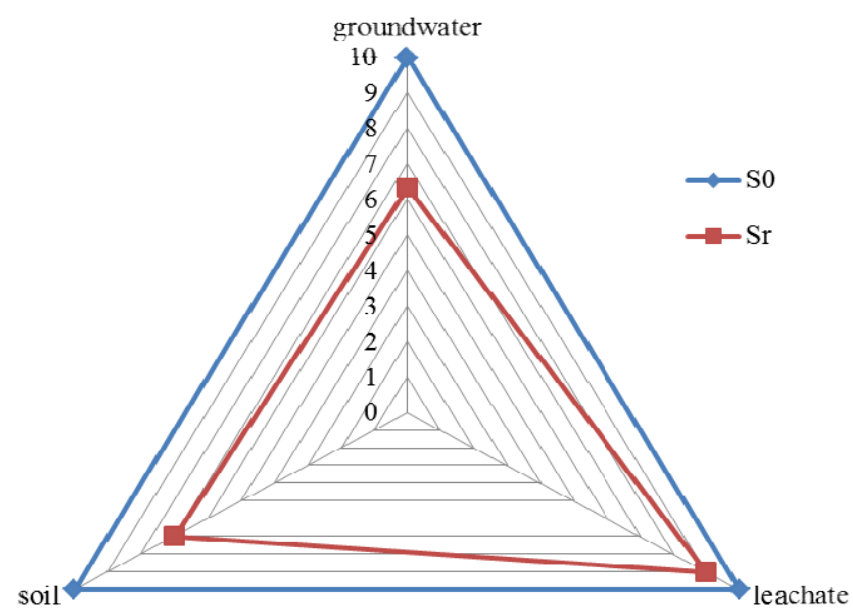

Fig. 5. Global Pollution Index $\left(\operatorname{Ip}_{\mathrm{G}}\right)$ chart 
These values were design on Creditworthiness notes chart (Fig. 5) resulting an asymmetrical triangle. The value of the Global Pollution Index $\left(\mathrm{Ip}_{\mathrm{G}}\right)$ calculated with Eq. (2) is 1.438 . This value means that the effect of the heavy metals from the sludge deposit on the environment, for the period analysed, is in acceptable limits (Table 2).

\section{Conclusions}

Sustainable development in the industrial sector is assessed, among other things, by how produced waste affects environmental factors.

To assess the impact of sludge on the environment, four factors are taken into account: the sludge composition, soil, groundwater and leachate produced in the landfill. The results obtained by the measurements, before sludge storage and during ten years of storage, showed the presence of dangerous substances in the sludge, the most significant effect being in the form of heavy metals $(\mathrm{Cu}, \mathrm{Zn}$ and $\mathrm{Fe})$, substances that were transferred to the environment: soil, groundwater and leachate. With the working method supported by the literature, method of the Creditworthiness notes, it has been interpreted the effect of each element on the environment by comparing the ideal / reference value and the real value at a certain time.

The study's results show that in the first 42 months soil and groundwater have undergone changes by aggregating the effects of the sludge deposit and the influence of a non-permeable deposit situated nearby, steel slag deposit that was closed after 42 months of opening the study. Over the next six years, the level of heavy metal contamination decreases to values close to the reference levels (Fig. 1 to 4 ). The global effect of heavy metals on the physical environment (ground and groundwater) was established using the Global Pollution Index (Fig. 5) and the result is: Environment subjected by human activity within acceptable limits (Table 2).

\section{References}

1. U.M. Uwem, D.M. Sunday, A.F. Wosilat, U.U Jonah, Science Journal of Analytical Chemistry, 7, 1 (2019)

2. M.F.L. Barbosa, A.B.S. Pironcelli, C.A. Silva et al., Asian J. Civ. Eng. (2019)

3. U.M. Uwem, D.M. Sunday, Chemical Science International Journal, 23, 4 (2018)

4. H. Bauman-Kaszubska, M. Sikorski, Journal of Ecological Engineering, 19, 6 (2018)

5. L. Chiriac, Buletin AGIR, 4 (2016)

6. C. Preda, Dissertation, (UPB, 2016)

7. $* * *$ NTPA $001 / 2002$ Normative on the setting of pollutant loading limits for industrial and urban waste water when discharged into natural receptors

8. $* * *$ Reference Document on Best Available Techniques Reference on Emission from Storage (2006)

9. ***Reference Document on Best Available Techniques for the Waste Treatments Industries (2006); Final Draft (October 2017)

10. V. Rojanschi, F. Grigore, V. Cimos, Valuer's Guide and Environmental Auditor's Guide (2008) 